\title{
PSYCHE
}

VOL. XXXI.

APRIL 1924

No. 2

\section{A NEW SPECIES OF SCHIZASPIDIA (EUCHARIDÆ), WITH NOTES ON A EULOPHID ANT PARASITE. ${ }^{1}$}

\author{
By George C. Wheeler and Esther Hald Wheeler.
}

Schizaspidia polyrhachicida new species

(Fig. 1.)

Female. Head small, three times as broad as long in dorsal view; but little narrower than the width of the thorax. Ocelli almost in a straight line, the outer ones less than an ocellusdiameter behind, the central one sunk in a grove which includes the antennal insertions. Head nearly twice wider than deep. Distance from ocellus to clypeus five-sevenths that from eye to eye. Malar line about equal to base of clypeus. Upper twothirds of face striated vertically; those striæ nearest the antennal groove curved medially and continuous with transverse striæ below antennæ and also behind ocelli; those nearest the eyes continuous with transverse striæ on the vertex. Lower third of face smooth. Transverse striæ arising at either side of clypeus and passing backward across the genæ and then upward behind the eye. Clypeus smooth. Antennæ twelve-segmented, extending nearly to the metascutellum; first segment one-half, and second segment one-third the length of the third, which is one-third as wide as long; fourth three-fourths of third; remaining segments of equal length, about one-half of third. Labrum with eight digitiform processes on its anterior border. Mandibles long, falciform; the right one with two teeth at the inner base, the left with one larger tooth.

Thorax as long as wide dorsally, coarsely reticulate-rugose.

${ }^{1}$ Contribution from the Zoological Department in the Liberal Arts College, Syracuse University. 
Prothorax extremely suppressed. Scutellar protuberance short, one-third the length of the scutellum, terminating in two short, asymmetrical prongs separated by a distance greater than their length. A wide reticulate-rugose channel extending from the base of the protuberance to the anterior border of the metascu-

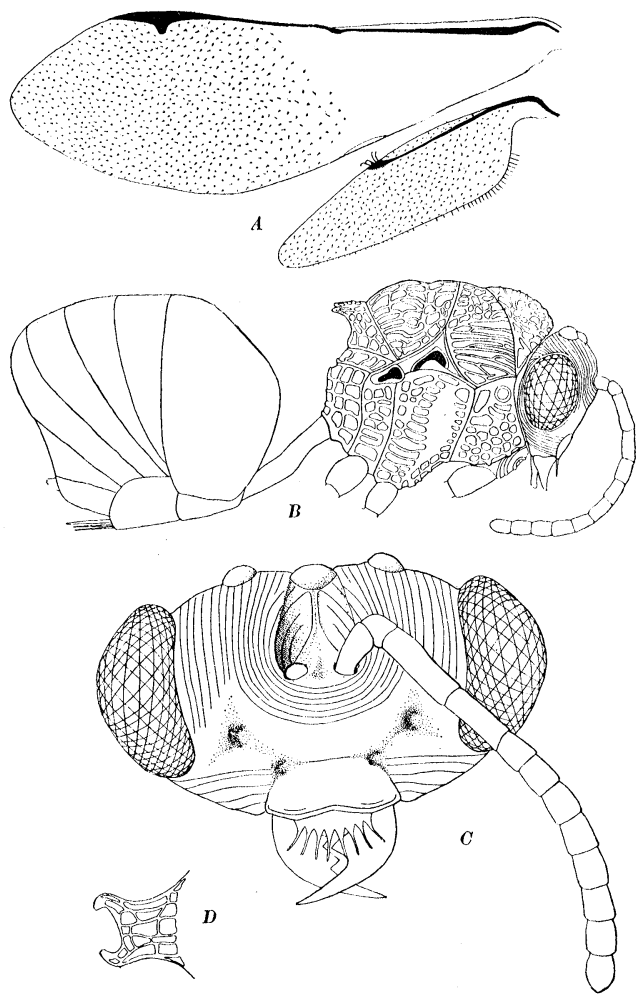

Fig. 1. Schizaspidia polyrhachicida n. sp. O . A, wings; B, lateral view; C, head in front view; D, metascutellar protuberance in dorsal view.

tum, where it is dilated into a deep pit surrounded by a ridge. Wings hyaline, reaching a little beyond the apex of the abdomen. Apical three-fifths of fore wing and entire hind wing finely hairy. 
Hind wing with vein extending to hooks, which are four in number, and with a fringe of cilia on the posterior border. Tibial spurs simple.

Gaster nearly twice as long as broad dorsally. Petiole less than one-half the length of the gaster, almost as long as the hind femur (13:14), and extending from the base of the propodeum to the lower margin of the gaster. First gastric segment partly inclosing the two following segments. Ovipositor without barbs, exposed for one sixth of the length of the gaster.

Head and thorax aëneous, except antennæ and mandibles which are fulvous with fuscous inner borders. Legs fulvous, except dark brown metacoxæ. Abdomen dark brown with these exceptions: dorsal spot on pedicel and most of first segment of gaster fuscous, rest of pedicel fulvous.

Length: $3.5 \mathrm{~mm}$. Host.-Polyrhachis (Myrmhopla) dives F. Smith.

Type Locality.-Manila, Philippine Islands. Described from two mature female pupæ found in cocoons of the host collected by McGregor. The ants are from Professor W. M. Wheeler's collection.

This species is near $S$. tenuicornis Ashmead, but is readily distinguishable from it by the pit on the metanotum. Mr. A. B. Gahan has very kindly compared a specimen with Ashmead's types in the United States National Museum.

The head of the parasitic pupa was at the anterior pole of the host cocoon, and its brilliant vermilion eyes were readily visible through the silken walls of the latter. The host pupa (phthisergate) had been almost completely drained of its contents, scarcely more than the exoskeleton remaining; this was pressed against the venter of the parasite.

This is the fourteenth species of Schizaspidia to be described, but only the third host record. ${ }^{2}$ Mr. Curtis P. Clausen (1923) has recently shown what an interesting field of investigation the biology of this widely distributed genus affords. All the Eucharidæ, for that matter, probably have the same possibilities.

${ }^{2} S$. doddi Bingham.-Camponotus sp. (Dodd, 1906).

S. ternucornis Ashmead.-Camponotus herculeanus japonicus May (Clausen, 1923). 
So far as is known, they parasitize ants exclusively. We have been able to find host records for twenty-one species in thirteen genera. The life histories of Orasema viridis Ashmead (Wheeler, 1907), Psilogaster fasciiventris Brues (1919), and Schizaspidia tenuicornis Ashmead (Clausen, 1923) are known. All three have planidium larvæ in the first stage.

Catalogue of the Gentus Schizaspidia Westwood.

caeruleiceps Cameron. $\sigma^{7}$. Borneo: Kuching.

Schizaspidia cceruleiceps Cameron, Entomologist, vol. 42, p. 231 (1909).

caffra Westwood. $0^{7}$ ? Africa: Caffraria.

Schizaspidia caffra Westwood, Thesaur. Entom. Oxon., p. 152 ; plate 28, fig. 12 (1874). Dalla Torre, Cat. Hym., vol. 5, p. 363 (1898). Schmiedeknecht, Gen. Insect, fasc. 97, p. 76 (1909).

cyanea Walker. $0^{7}$. Moluccas: Amboina.

Schizaspidia cyanea Walker, Trans. Entom. Soc. London (3) vol. 1, p. 386 (1862). Dalla Torre, Cat. Hym. vol. 5, p. 363 (1898). Schmiedeknecht, Gen. Insect., fasc. 97, p. 76 (1909).

doddi Bingham. $\sigma^{\top}$. Queensland: Townsville.

Schizaspidia doddi Dodd, Trans. Entom. Soc. London, p. 123 (1906). Girault, Mem. Queensland Mus., vol. 4, p. 235 (1915).

furcifera Westwood. $0^{7}$ ? $\circ$ ? Asia: Eastern India and Bengal Schizaspidia furcifer Westwood, Proc. Zool. Soc. London, vol. 3, p. 69 (1835).

Schizaspidia furcifera Westwood, Thesaur. Entom. Oxon., p. 151, plate 28, fig. 2 (1874). Kirby, Journ. Linn. Soc. London, Zool., vol. 20, p. 31 (1886). Dalla Torre, Cat. Hym., vol. 5, p. 364 (1898). Schmiedeknecht, Gen. Insect, fasc. 97, p. 76 (1909).

maculata Westwood. ㅇ. Brazil; Central Goyaz.

Schizaspidia (?) maculata Westwood, Thesaur. Entom. Oxon., p. 153, plate 28, fig. 1 (1874). 
Orasema maculata Kirby, Journ. Linn. Soc. London, Zool., vol. 20, p. 29, plate 1, fig. 1 (1886). Dalla Torre, Cat. Hym., vol. 5, p. 361 (1898). Ashmead, Mem. Carnegie Mus., vol. 1, p. 469 (1904).

Schizaspidia maculata Schmiedeknecht, Gen. Insect., fasc. 97, p. 76, (1909).

murrayi Kirby. $\sigma^{7}$. Tonga Islands: Tongatabu.

Schizaspidia murrayi Kirby, Ann. \& Mag. Nat. Hist., (5) vol. 13, p. 403 (1884). Kirby, Journ. Linn. Soc. London, Zool., vol. 20, p. 37, (1886). Dalla Torre, Cat. Hym. Vol. 5, 364 (1898). Schmiedeknecht, Gen. Insect., fasc. 97, p. 76 (1909). Girault, Mem. Queensland Mus., vol. 4, p. 235 (1915).

polyrhachicida G. Wheeler \& E. Wheeler. ․ Philippine Islands: Manila.

Schizaspidia polyrhachicida G. Wheeler \& E. Wheeler, Psyche, vol. 31, p. 49.

pretendens Walker. $\sigma^{\top}$. Brazil: Villa Nova.

Schizaspidia pretendens Walker, Trans. Entom. Soc. London, (3) vol. 1, p. 385 (1862). Dalla Torre, Cat. Hym., vol. 5, p. 364 (1898). Ashmead, Mem. Carnegie Mus., vol. 1, p. 469 (1904). Schiemdeknecht, Gen. Insect., fasc. 97, p. 76 (1909).

quinqueguttata Girault. $\sigma^{7}$. Queensland: Gordonville (Cairns). Schizaspidia quinqueguttata Girault, Mem. Queensland Mus., vol. 4, p. 235 (1915).

rudis Westwood. sex? South Australia: Angas.

Schizaspidia rudis Westwood, Thesaur. Entom. Oxon., p. 152, plate 28, fig. 5 (1874). Dalla Torre, Cat. Hym., vol. 5, p. 364 (1898). Schmiedeknecht, Gen. Insect., fasc. 97, p. 76 (1909). Girault, Mem. Queensland Mus., vol. 4, p. 235 (1915).

septentrionalis Brues. 우. Arizona: Huachuca Mts.

Schizaspidia septentrionalis Brues, Bull. Wisconsin Nat. Hist. Soc., vol. 5, p. 104 (1907).

tenuicornis Ashmead. $\odot \sigma^{x}$. Japan: Northern Hondo and Hokkaido. Korea. 
Schizaspidia tenuicornis Ashmead, Journ. New York Entom. Soc., vol. 12, p. 151 (1904). Clausen, Ann. Entom. Soc. America, vol. 16, p. 195-215 (1923).

trimaculata Cameron. $\%$. Borneo: Kuching.

Schizaspidia trimaculata Cameron, Deutsch. Entom. Zeitschr., p. 205, (1909).

\section{A EULOPHID ANT PARASITE}

While examining a vial of ants (Crematogaster acuta Fabr.) collected by Professor W. M. Wheeler at Kartabo, British Guiana in the summer of 1920, we found that twenty-six of the larvæ were parasitized. In one instance, the parasites were pigmented pupæ, not, however, mature enough for identification. They were sent to Mr. A. B. Gahan, who reported as follows: "This is an Eulophid, apparently closely related to the genus Paracrias Ashmead, but I cannot identify it positively, even generically."

Of these twenth-six larvæ, twelve contained one parasite, thirteen contained two, while one contained four-a total of forty-one parasites, of which nineteen were larvæ and twenty-two were pupæ. Eleven host larvæ contained pupal parasites sufficiently developed for the sex to be evident: four contained one parasite (female); seven contained two-a male and a female in every case. With two parasites in one host, the heads of the former were at the caudal and of the latter. Of the four containing only one parasitic pupa, two had the heads directed towards the anterior end and two towards the posterior end of the host.

Figure 2 shows the mature pupæ referred to above-a male (length $2.0 \mathrm{~mm}$.) on the right and a female (length $2.4 \mathrm{~mm}$.)with their ventral surfaces contiguous and occupying the greater part of the host's interior. The cloudy mass posterior to the pupæ is apparently a residue of host tissues, but probably also contains the meconia of the parasites.

The Eulophid larvæ are elongate, cylindrical, and entirely destitute of hairs. The button-like head is small, subterminal and elliptical in oral view. The conspicuous mandibles are falciform and sharp-pointed. 


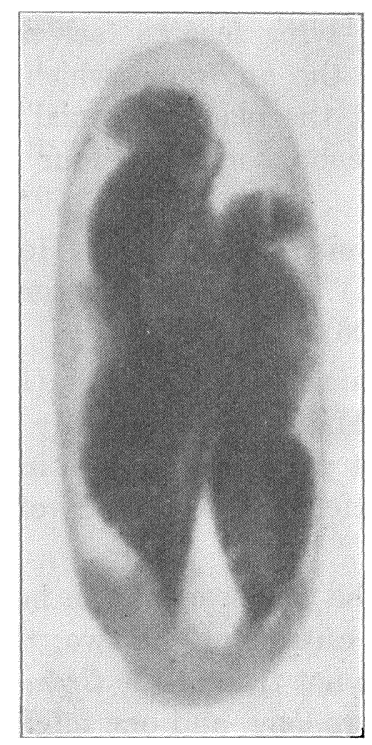

Fig. 2. Pupae of Eulophid parasite in larva of Crematogaster acuta Fabr.

This is, so far as we know, the only record of a Eulophid with an ant host. Although it cannot be stated definitely that the Eulophid is a primary parasite of the ant, it would seem that such is probably the case as none of the ant larvæ showed signs of parasitism by any other species.

Among the Chalcidoidea it is not unusual to find several parasites developing in a single host. In the Chalcididæ and Proctotrypidæ, where polyembryony occurs the number may reach a hundred, perhaps more. But this is not a case of polyembryony, for here both sexes occur within the same host individual. Whether all the parasites in a host larva are offspring of the same mother or whether two or more females have oviposited in one host (epiparasitism of Haviland) cannot, of course, be determined from our material. Among the Eucharidæ there are three records of this multiple parasitism:

Pseudochalcura gibbosa Provancher. (Host-Camponotus herculeanus ligniperdus var. noveboracensis Fitch.) "In one of the 
cocoons,..$\ldots \ldots \ldots$. there were two pigmented and therefore nearly mature pupæ, lying face to face near the anterior pole while the remains of the ant pupa which they had consumed, were crowded against the black meconial spot at the posterior pole. The other cocoon contained four unpigmented pupæ." (Wheeler, 1907).

Rhipipallus affinis Bingham. (Host-Odontomachus ruficeps coriaria Mayr.)"..........sometimes several from one cocoon." (Dodd, 1906).

Schizaspidia tenuicornis Ashmead. (Host-Camponotus herculeanus japonicus Mayr) "Occasionally two larvæ may be found on a single host pupa, and in such instances their position is symmetrical with reference to the body of the host." (Clausen 1923).

In all three of the above cases the host pupa is large and could easily provide nutriment for two, three or perhaps four parasites. But this is not true of the Crematogsater larvæ, which are only 2.8 millimeters long, and one might wonder whether on this ant multiple parasitism is generally successful.

\section{LITERATURE CITED.}

1919. Brues, C. T. Ann. Entom. Soc. America, vol. 12, pp. 13-21.

1923. Clausen, C. P. Ann. Entom. Soc. America, vol. 16, pp. 195-217.

1906. Dodd, F. P. Trans. Entom. Soc. London, pp. 119-132.

1907. Wheeler, W. M. Bull. American Mus. Nat. Hist., vol. 23, pp. 1-93. 

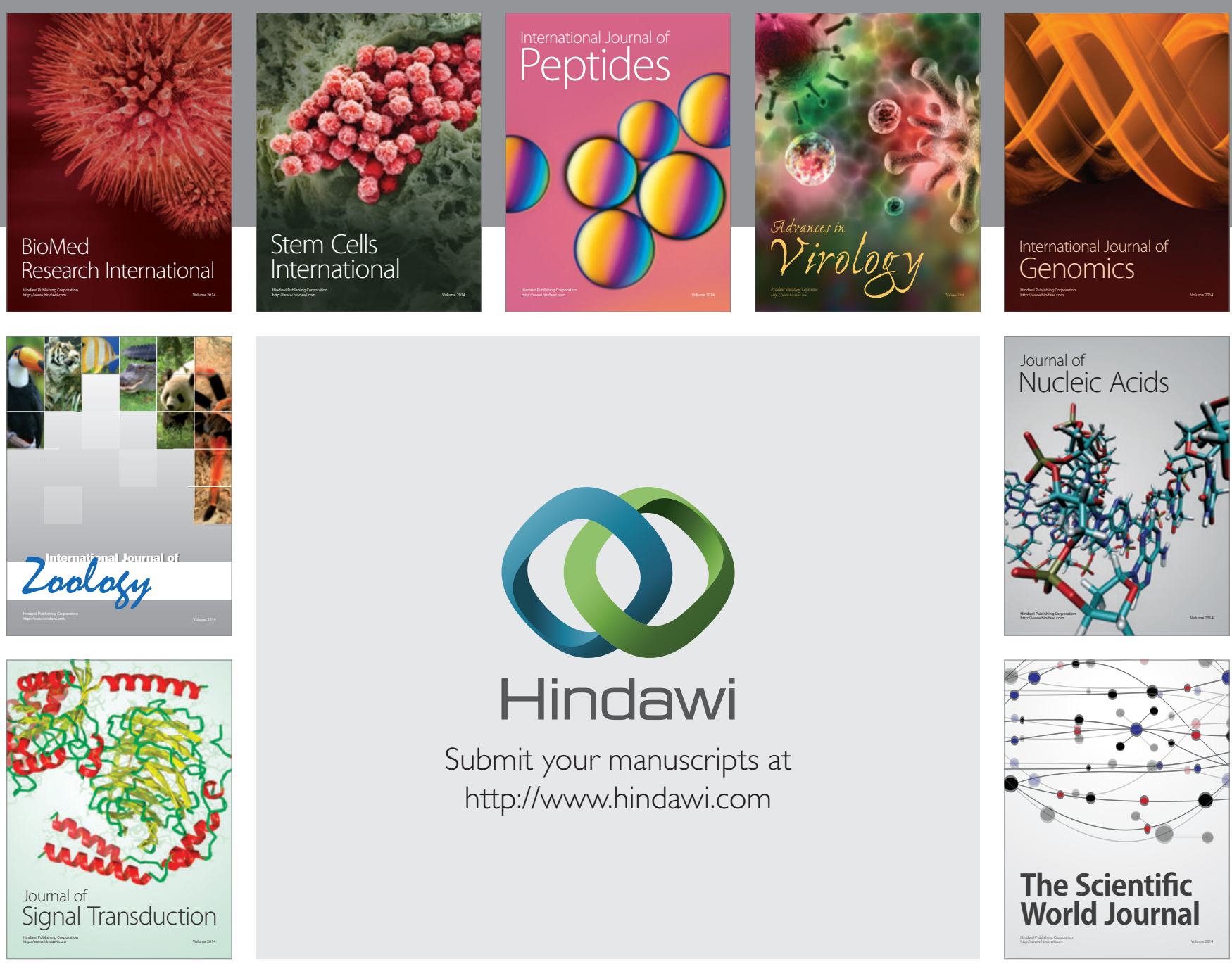

Submit your manuscripts at

http://www.hindawi.com
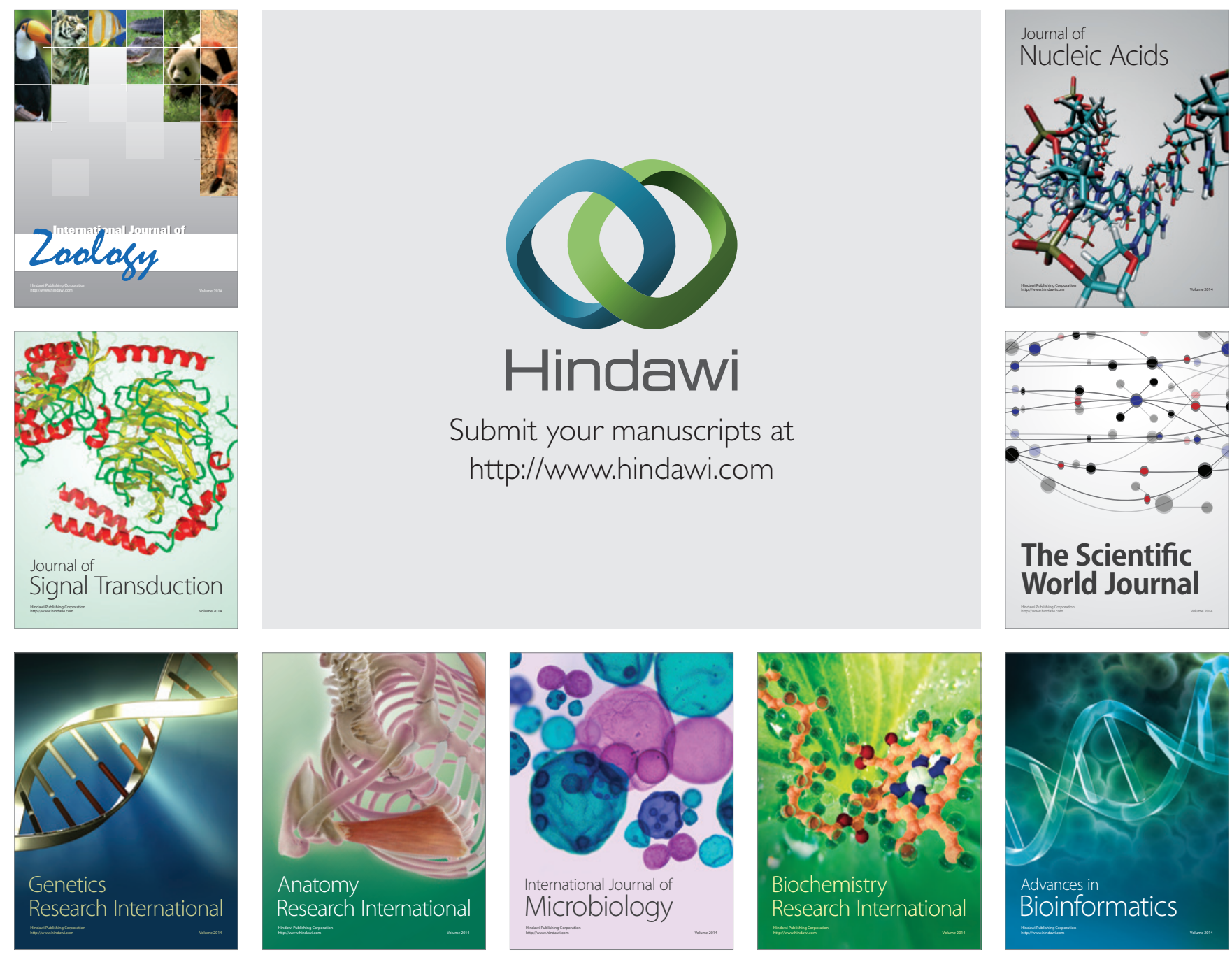

The Scientific World Journal
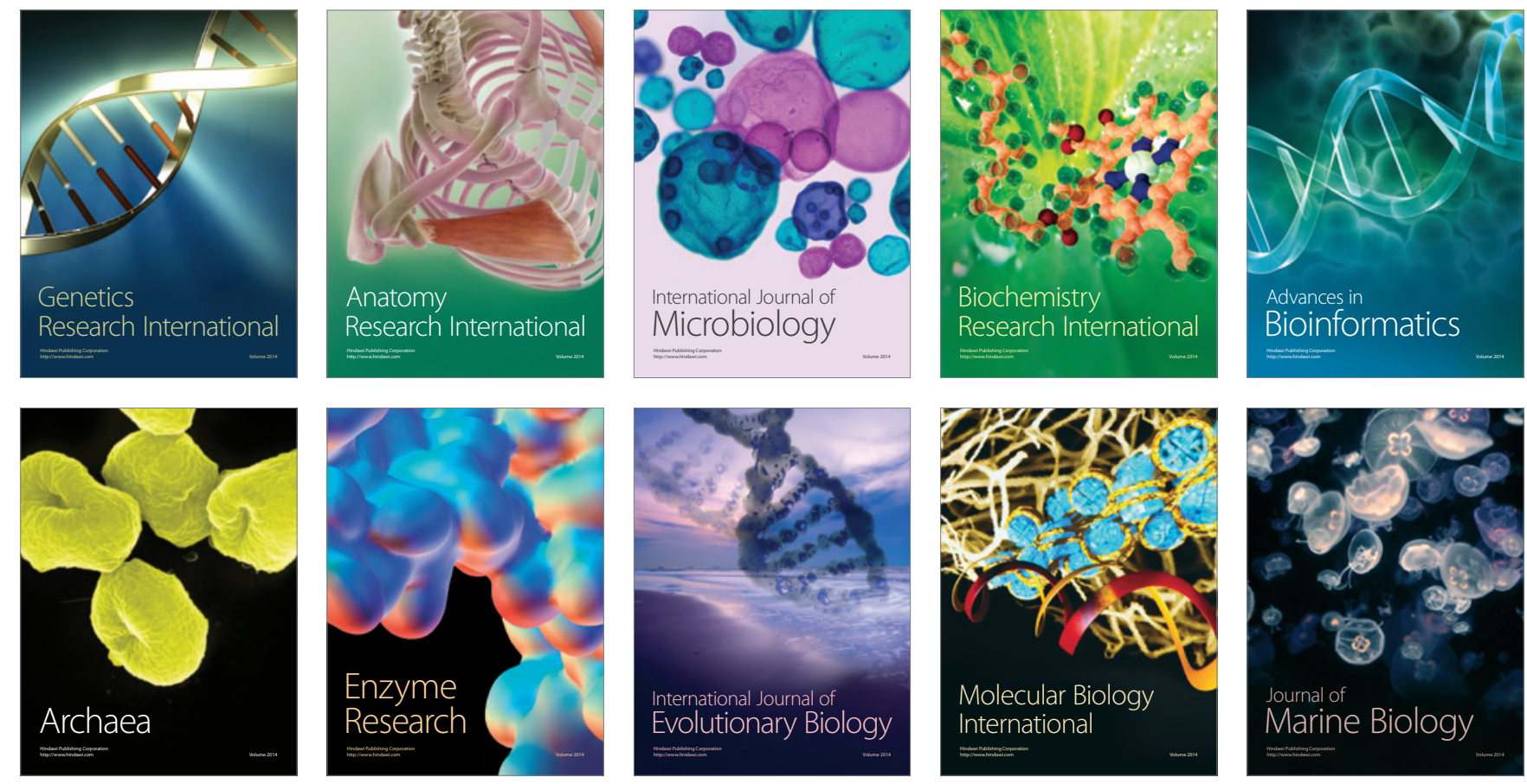